\title{
PENGARUH KEADILAN ORGANISASIONAL DAN KOMPENSASI FINANSIAL TERHADAP KEPUASAN KERJA DAN ORGANIZATIONAL CITIZENSHIP BEHAVIOR
}

\author{
Ni Made Reni Budi Dhamayanti ${ }^{1}$ \\ I Gede Adnyana Sudibya ${ }^{2}$
}

\author{
${ }^{1,2}$ Fakultas Ekonomi dan Bisnis Universitas Udayana (Unud), Bali, Indonesia \\ E-mail:reni_damayanti30@yahoo.com
}

\begin{abstract}
ABSTRAK
Tujuan dari penelitian ini adalah untuk mengetahui pengaruh keadilan organisasional dan kompensasi finansial terhadap kepuasan kerja dan organizational citizen behavior. Penelitian ini dilakukan di PT. Dwi Eka Bakti Denpasar. Jumlah sampel yang diambil sebanyak 40 orang karyawan sebagai responden dengan metode sampling jenuh. Pengumpulan data dilakukan melalui metode survey. Teknik analisis data yang digunakan adalah analisis jalur (path analysis dengan program SPPS for Windows. Berdasarkan hasil analisis ditemukan bahwa seluruh hipotesis diterima. Keadilan organisasional berpengaruh positif dan signifikan terhadap kepuasan kerja, kompensasi finansial berpengaruh positif dan signifikan terhadap kepuasan kerja, keadilan organisasional berpengaruh positif terhadap OCB, kompensasi finansial berpengaruh positif dan signifikan terhadap OCB, kepuasan kerja berpengaruh positif dan signifikan terhadap OCB. Perusahaan diharapkan dapat menerapkan sebuah peraturan baku yang telah disepakati bersama serta mampu diterapkan dan ditaati secara konsisten, mampu memberikan kesejahteraan baik finansial maupun non-finansial kepada karyawannya sesuai dengan beban kerja masing-masing.
\end{abstract}

Kata Kunci: keadilan organisasional, kompensasi finansial, kepuasan kerja, organizational citizenship behavior

\begin{abstract}
The purpose of this study was to determine the effect of organizational justice and financial compensation on job satisfaction and organizational citizen behavior. This research was conducted at PT. Dwi Eka Bakti Denpasar. The number of samples taken as many as 40 employees as respondents with saturated sampling method. Data collection is done through survey methods. The data analysis technique used is path analysis (path analysis with SPPS for Windows program. Based on the analysis found that all hypotheses are accepted. Organizational justice has a positive and significant effect on job satisfaction, financial compensation has a positive and significant effect on job satisfaction, organizational justice has a positive effect with regard to $O C B$, financial compensation has a positive and significant effect on $O C B$, job satisfaction has a positive and significant effect on $O C B$, the company is expected to implement a standard rule that has been mutually agreed upon and is able to be consistently implemented and adhered to, able to provide financial and nonfinancial welfare to employees are in accordance with their respective workloads.
\end{abstract}

Keywords: organizational justice, financial compensation, job satisfaction, organizational citizenship behavior 


\section{PENDAHULUAN}

Perusahaan membutuhkan karyawan yang mampu bekerja lebih baik dan lebih cepat, maka dari itu kinerja karyawan menjadi sangat penting untuk diperhatikan dengan alasan bahwa perusahaan membutuhkan karyawan yang mau bekerja secara efektif dan efesien (Devi dan Sintaasih, 2016). Karyawan diharapkan bekerja tidak hanya sebatas tugas inti karyawan tersebut, melainkan perusahaan sangat memerlukan karyawan yang siap dan mau bekerja in-role dan extra-role, dimana prilaku ini menjadi tuntutan di setiap perusahaan agar dapat bersaing dan mencapai tujuan organisasi. Prilaku extra-role yang paling sering menjadi tuntutan perusahaan atau organisasi dimana karyawan mau bekerja lebih dari yang seharusnya dilakukan atau diluar tugas formal mereka (Rini dkk., 2013).

Dalam penelitian (Perdana, 2010) menyatakan Perilaku extra-role atau disebut juga dengan perilaku Organizational Citizenship Behavior (OCB) merupakan perilaku yang tampak dan dapat diamati. Robbins dan Judge (2008:40) menyatakan bahwa karyawan dalam suatu perusahaan yang dapat memahami OCB (Organizational Citizenship Behavior) dengan baik, maka kinerjanya lebih baik dibandingkan karyawan yang tidak memahami OCB dengan baik. Kinerja individu dan kinerja organisasi dapat berkembangan dengan baik apabila didukung oleh perilaku positif dari karyawan (Salwa et al., 2011).

PT. Dwi Eka Bakti merupakan salah satu perusahaan Kontraktor yang bergerak di bidang jasa pelaksana konstruksi, sipil dan supplier untuk pengadaan barang mekanikal elektrikal dengan konsumen utamanya adalah PT. PLN (Persero). PT. Dwi Eka Bakti sangat mengutamakan kualitas yang ditawarkannya baik berupa jasa atau barang. Adanya persaingan yang ketat antar sesama 
perusahaan kontraktor dengan bidang yang sama dalam mendapatkan pekerjaan di PT. PLN (Persero) mengharuskan PT. Dwi Eka Bakti memiliki karyawan yang berkualitas yang mampu bekerja secara kreatif, disiplin, dan bersedia melakukan pekerjaan diluar tugas inti(extra job-role) atau yang disebut dengan OCB.

Perilaku OCB di dalam tim kerja dapat menciptakan suasana yang kondusif, saling menguatkan, saling menopang dan saling mengisi, sehingga stabilitas perusahaan terjaga dan kinerja akan semakin membaik. OCB dapat dijadikan sebagai dasar yang efektif untuk aktivitas-aktivitas koordinasi antar anggotaanggota tim dan antar kelompok-kelompok kerja. Organ et al. (2006) mendefinisikan OCB sebagai perilaku individual yang bersifat bebas (discretionary), yang tidak secara langsung dan eksplisit mendapat penghargaan dari sistem imbalan formal, dan yang secara keseluruhan mendorong keefektifan fungsi-fungsi organisasi.Waspodo (2012) menjelaskan bahwa OCB merupakan prilaku sukarela dari seseorang pekerja untuk mau melakukan tugas atau pekerjaan diluar tanggung jawab atau kewajiban demi kemajuan atau keuntungan organisasi. Artinya seseorang yang memiliki perilaku OCB tinggi tidak mengharapkan bayaran dalam bentuk uang atau bonus melainkan OCB lebih kepada perilaku sosial dari individu untuk bekerja melebihi apa yang diharapkan.

Dari hasil observasidan wawancara awal dengan beberapa karyawan pada PT. Dwi Eka Bakti ditemukan beberapa masalah terkait dengan prilaku OCB karyawan, dimana tingkat OCB yang dimiliki karyawan rendah. Hal ini terlihat pada saat adanya penumpukan pekerjaan pada salah satu karyawan maka rekan kerja lain enggan untuk mau membantu, sering adanya perdebatan dan 
Ni Made Reni Budi Damayanti, Pengaruh......

perselisihan paham antar sesama karyawan. Beberapa karyawan lebih sering memanfaatkan waktu kerja untuk mengurus kepentingan pribadinya, beberapa dari karyawan juga kurang tertarik akan kegiatan-kegiatan yang diadakan oleh perusahaan.

Rendahnya perilaku OCB pada karyawan PT. Dwi Eka Bakti akan berdampak pada kinerja serta prestasi karyawan secara keseluruhan. Perilaku OCB terjadi jika adanya umpan positif dari karyawan yang merasa puas terhadap hal-hal yang telah diperolehnya. Danan dan Hasanbasri (2007) dalam penelitiannya menyatakan hubungan positif dan signifikan kepuasan kerja dengan organizational citizenship behavior. Penelitian menunjukkan seorang karyawan yang puas terhadap pekerjaannya lebih cenderung bertahan pada organisasi dan bekerja dengan maksimal demi perkembangan organisasi. Kepuasan kerja yang dirasakan oleh karyawan menghasilkan peningkatan pada Organizational citizenship behavior (OCB) yang akan berpengaruh pada kinerja mereka dalam organisasi (Swaminathan dan Jawahar, 2013).

Kepuasan kerja merupakan sesuatu yang tidak dapat diukur hanya dari pengamatan fisik semata. Kepuasan kerja hanya dapat disimpulkan apabila pekerja secara langsung menyatakan puas/tidaknya mereka dengan pekerjaan yang dilakukan (Devi dan Sintaasih, 2016). Faruk (2013), seseorang yang merasa puas dengan pekerjaannya akan cenderung berperilaku positif terhadap organisasi tempatnya bekerja. Hal itu terjadi karena karyawan dengan kepuasan kerja yang tinggi memiliki semangat kerja yang tinggi pula, sehingga prestasi kerjanya akan 
maksimal pula, sebaliknya karyawan dengan kepuasan kerja yang rendah akan menyebabkan prestasi kerjanya menjadi buruk (William dan Setiawan, 2013).

Balas jasa yang diberikan karyawan terhadap perusahaan atas kepuasan kerja yang telah disumbangkan kepada perusahaan adalah perusahaan wajib memberikan segala imbalan dalam bentuk uang, barang maupun kenikmatan sebagai penghargaan atas kinerja yang telah diberikan. Dari pengamatan pada PT. Dwi Eka Bakti Karyawan masih sering mengeluh tentang beban kerja yang diberikan tidak sesuai dengan penghasilan atau insentif yang diterima untuk memenuhi kebutuhan mereka, sehingga karyawan akan mengeluh jika dihadapkan pada situasi yang tidak menguntungkan yang akan menyebabkan rendahnya prilaku OCB. Penelitian yang dilakukan oleh Choi et al. (2015) menyatakan reward memiliki efek positif terhadap perilaku OCB. Penelitian Islamet al. (2012) juga menyatakan adanya hubungan yang positif dan signifikan antara kompensasi dan kepuasan kerja karyawan. Kompensasi dibagi menjadi dua yaitu kompensasi finansial dan kompensasi non finansial, dalam perusahaan kompensasi finansial yang sangat dibutuhkan oleh karyawan. Ahmad et al. (2012) menyatakan faktor kompensasi finansial langsung yang dioperasionalkan pada perusahaan berupa gaji, insentif dan bonus, secara umum sangat mempengaruhi karir karyawan dalam perusahaan. Kompensasi finansial harus diperhatikan dengan baik karena hal ini akan meningkatkan kinerja karyawan yang nantinya akan menguntungkan kedua belah pihak, dari karyawan maupun perusahaan. Lewa dan Subowo dalam Riyadi (2011) menyatakan bahwa kompensasi yang diberikan harus layak, adil, dapat diterimakan, memuaskan, memberi motivasi kerja, bersifat penghargaan dan 
sesuai dengan kebutuhan. Saat kompensasi dirasakan layak dan adil oleh seluruh karyawan maka hal ini akan menimbulkan hubungan positif antara karyawan dengan perusahaan.

Pengembangkan prilaku adil harus selalu diterapkan atasan kepada semua bawahannya secara konsisten dan tegas, baik pembagian tugas pada masingmasing individu dan dalam setiap pengambilan keputusan. Keadilan organisasional memiliki keterkaitan dengan kepuasan kerja, hal ini mempengaruhi kepuasan kerja karyawan (Cropanzano et al., 2007). Keadilan organisasional adalah konsep persepsi karyawan mengenai sejauh mana mereka diperlakukan adil dalam organisasi dan hal tersebut mempengaruhi loyalitas karyawan terhadap organisasi (Greenberg, 1990 dalam Najafi et al., 2011). Dalam penelitian Fatimah et al. (2011) menemukan bahwa semakin besar rasa keadilan yang dirasakan seseorang akan meningkatkan rasa kepuasan pada pekerjaan yang dimiliki orang tersebut. Ketika pimpinan perusahaan mampu berlaku adil dan konsisten kepada seluruh karyawannya maka akan meningkatkan kepuasan kerja serta komitmen mereka, dimana karyawan akan bekerja tanpa beban dan tidak adanya perasaan iri satu sama lainnya. Hal ini akan secara tidak langsung mampu menciptakan adanya perilaku OCB yang tinggi. Penelitian Roohi dan Feizi (2013) mengungkapkan bahwa keadilan organisasi dan dimensi dari keadilan organisasional memiliki hubungan positif signifikan dengan OCB. Swaminathan dan Jawahar (2013) membuktikan bahwa kepuasan kerja menjadi korelasi yang sangat erat dengan Organizational citizenship behavior (OCB), sehingga orang-orang yang lebih puas dengan pekerjaanya lebih mungkin terlibat dalam Organizational citizenship 
behavior (OCB). Maka dalam hal ini peneliti memilih empat variabel yaitu, keadilan organisasional, kompetensi finansial, kepuasan kerja dan organizational citizenship behavior (OCB).

Ratnaningsih (2013) menjelaskan OCB merupakan perilaku positif karyawan dalam membantu pekerjaan individu lain dalam organisasi atau perusahaan. Kontribusi yang ditunjukkan oleh pekerja itu berupa pekerjaan diluar pekerjaan yang harus dilakukannya, dengan menunjukkan perilaku menolong orang lain dalam sebuah perusahaan sehingga tindakan tersebut mungkin dapat memperbaiki kinerja organisasi atau perusahaan tersebut. Waspodo (2012) menjelaskan bahwa OCB secara sederhana dapat dikatakan sebagai prilaku individu yang berakar dari kerelaan diri untuk memberikan kontribusi melebihi peran inti atau tugasnya terhadap perusahaan. Prilaku tersebut dilakukan, baik secara disadari maupun tidak disadari, diarahkan maupun tidak diarahkan, untuk dapat memberikan manfaat dan keuntungan bagi perusahaan.

Terdapat tiga kategori perilaku pekerja yang dikemukakan Huang et al. (2012) yaitu: (1) berpartisipasi, terikat dan berada dalam satu organisasi; (2) harus menyelesaikan suatu pekerjaan dan bertindak sesuai dengan prinsip-prinsip yang diatur oleh organisasi; serta (3) melakukan aktifitas yang inovatif dan spontan melebihi persepsi perannya dalam organisasi, kategori terakhirlah yang sering disebut sebagai organizational citizenship behavior (OCB) atau extra-role behavior.

Kepuasan kerja adalah pandangan karyawan yang menyenangkan atau tidak menyenangkan terhadap pekerjaan mereka. Perasaan tersebut akan tampak dari 
sikap positif karyawan terhadap pekerjaan dan segala sesuatu yang dihadapi di lingkungan kerjanya (Handoko, 2001:193). Pendapat lain mengenai kepuasan kerja yaitu Suwardi (2011) menjelaskan kepuaskan kerja memberikan sumbangan besar terhadap keefektifan suatu organisasi, serta loyalitas karyawan. Kepuasan berorientasi pada sikap individu karyawan terhadap tugasnya, karyawan yang tingkat kepuasan kerja yang tinggi maka akan memiliki sikap positif terhadap kewajibannya, sedangkan yang tidak puas akan memiliki sikap negatif terhadap kewajibannya, maka kepuasan kerja adalah penilaian yang menunjukan perasaan sikap kepuasan dalam bekerja (Septiadi dan Supartha, 2013).

Lu et al. (2013) membagi kepuasan kerja ke dalam kepuasan kerja internal yaitu perasaan yang berasal dari hubungan individu dengan pekerjaan itu sendiri, dimana tingkat kepuasan tersebut diperoleh dari pekerjaan itu sendiri dan kepuasan kerja eksternal yaitu rasa kepuasan yang tidak berhubungan langsung antara alasan merasa puas dengan pekerjaan itu sendiri. Dalam Penelitian Anas (2013) menyatakan dengan terpeliharanya dan terjaganya kepuasan kerja karyawan, maka akan mendorong mereka untuk bekerja dengan semangat kerja yang tinggi dan pada akhirnya akan membantu secara efektif dan efisien pihak perusahaan dalam mencapai tujuan yang diinginkan perusahaan itu sendiri.

Kompensasi mempunyai peran penting dalam meningkatka kepuasan kerja dan kinerja (Yensi, 2010). Pemberian kompensasi merupakan sebuah balas jasa yang diberikan perusahaan baik berupa uang, barang, maupun kenikmatan yang diberikan oleh perusahaan kepada karyawan atas kepuasan kerja yang disumbangkan kepada perusahaan (Utama,dkk., 2001:261). Wibowo (2012:348) 
menyatakan kompensasi merupakan jumlah paket yang ditawarkan organisasi kepada pekerja sebagai imbalan atas penggunaan tenaga kerjanya. Erbasi dan Arat (2012) menyatakan bahwa jika program kompensasi yang diberikan perusahaan dirasa adil dan kompetitif maka, akan mempengaruhi kepuasan kerja karyawan. Dari beberapa pendapat ahli dapat dinyatakan bahwa kompensasi finansial merupakan segala sesuatu yang diberikan perusahaan kepada karyawan dalam bentuk uang (finansial) untuk balas jasa atas kontribusi yang diberikan pada perusahaan.

Keadilan organisasional merupakan suatu perlakuan, maupun tindakan yang diterima oleh setiap karyawan sama tanpa memandang status jabatan atau kedudukan dan dapat dikatakan adil apabila karyawan mendapatkan hak-hak mereka sesuai dengan apa yang mereka kontribusikan kepada perusahaan (Marissa, 2010). Menurut Robbins dan Judge (2015:144) Keadilan organisasional didefinisikan sebagai keseluruhan persepsi mengenai apa yang adil di dalam tempat kerja. Roohi dan Feizi (2013) menyatakan Konsep keadilan digunakan untuk menjelaskan mengapa karyawan dapat menilai wajar atau tidaknya keputusan yang dibuat oleh yang berwenang. Teori keadilan dari Stacey Adam (Mustafa, 2008) menyatakan setiap anggota organisasi akan membandingkan dirinya dengan hal lain (keadaan sebelumnya atau keadaan lingkungan di dalam organisasi maupun keadaan di luar organisasi).

Teori keadilan oleh Adam (Retnaningsih, 2007) meyebutkan dalam organisasi, peran keadilan yang diterima pegawai sangatlah besar dalam menjaga kepuasan kerja mereka. Penelitian yang dilakukan oleh Yasadiputra (2014) pada 
PT. Wico Internal, Singaraja-Balimenyatakan bahwa organizational justice memiliki pengaruh yang positif dan signifikan terhadap job satisfaction karyawan. Penelitian ini juga dilakukan oleh Fatimah et al. (2011) yang menemukan bahwa pengaruh yang signifikan dan positif dari keadilan organisasi terhadap kepuasan kerja. Sareshkeh et al. (2012) memperkuat dengan menyimpulkan bahwa semakin tinggi rasa keadilan yang dirasakan karyawan maka akan diikuti dengan semakin meningkatnya kepuasan kerja karyawan tersebut. Selanjutnya penelitian dilakukan oleh Fatt et al. (2010) menemukan bahwa keadilan distributif dan keadilan proseduran berpengaruh positif dan signifikan terhadap kepuasan kerja. Penelitian yang sama dilakukan oleh Widyaningrum (2010) menyatakan bahwa keadilan organisasi secara langsung berpengaruh positif dan signifikan terhadap kepuasan kerja dan komitmen pegawai. Berdasarkan landasan teori dan berbagai penelitian sebelumnya dapat dikemukakan hipotesis sebagai berikut :

$\mathrm{H}_{1}$ : Keadilan organisasional berpengaruh positif dan signifikan terhadap kepuasan kerja

Samudra dkk. (2014) menyatakan pemberian kompensasi finansial merupakan salah satu tugas dari fungsi personalia yang paling kompleks dan juga merupakan salah satu aspek yang paling berarti baik bagi karyawan maupun bagi organisasi. Islam et al. (2012) dalam penelitiannya menyatakan ada hubungan positif dan signifikan antara kopensasi dan kepuasan kerja. Penelitian juga dilakukan oleh Syah (2013) dengan menyimpulkan bahwa kompensasi finansial teruji berpengaruh positif terhadap kepuasan kerja dan motivasi kerja karyawan pada PT. Graha Raja Empat. Penelitian ini diperkuat oleh Leo (2014) menyatakan variabel kompensasi finansial berpengaruh secara signifikan terhadap kepuasan 
kerja karyawan. Penelitian juga dilakukan oleh Bhatti et al. (2011) menyatakan bahwa hubungan antara kompensasi dan kepuasan kerja karyawan memiliki hubungan positif dan signifikan. Selanjutnya, Kusumaningtyas dan Alwi (2012) dalam penelitiannya menyatakan bahwa variabel kompensasi finansial memiliki pengaruh yang signifikan terhadap kepuasan kerja karyawan. Erbasi dan Arat (2012) dalam penelitiannya memperkuat dengan menyatakan bahwa sebuah hubungan positif dan signifikan antara tingkat tinggi ditentukan antara insentif keuangan yang digunakan dalam rantai makanan local dan tingkat kepuasan kerja karyawan. Berdasarkan landasan teori dan berbagai penelitian sebelumnya dapat dikemukakan hipotesis sebagai berikut :

$\mathrm{H}_{2}$ : Kompensasi finansial berpengaruh positif signifikan terhadap kepuasan kerja

Penelitian yang dilakukan oleh Nwibere (2014) yang menunjukan bahwa persepsi tentang keadilan mempunyai pengaruh positif dan signifikan terhadap organizational citizenship behavior (OCB). Ketika karyawan merasa telah diperlakukan secara adil oleh perusahaan maka perilaku extra-role dari karyawan meningkat. Penelitian ini juga ditunjukkan dalam penelitian Ibrahim dan Perez (2014) menyatakan bahwa keadilan organisasional berpengaruh positif terhadap organizational citizenship behavior (OCB). Penelitian diperkuat oleh Roohi dan Feizi (2013) menyimpulkan bahwa keadilan organisasi dan dimensi dari keadilan organisasional memiliki hubungan positif dan signifikan dengan organizational citizenship behavior (OCB). Berdasarkan landasan teori dan berbagai penelitian sebelumnya dapat dikemukakan hipotesis sebagai berikut :

$\mathrm{H}_{3}$ : Keadilan organisasional berpengaruh positif dan signifikan terhadap organizational citizenship behavior (OCB). 
Ni Made Reni Budi Damayanti, Pengaruh......

Penelitian yang dilakukan oleh Angelina dan Subudi (2017) menyatakan bahwa kompensasi finansial berpengaruh positif dan signifikan terhadap organizational citizenship behavior (OCB). Penelitian juga dilakukan oleh Choi et al. (2015) menjelaskan bahwa reward memiliki efek positif terhadap OCB. Penelitian diperkuat oleh Tampi (2013) yang menyatakan bahwa kompensasi finansial berpengaruh positif signifikan terhadap organizational citizenship behavior (OCB). Berdasarkan landasan teori dan berbagai penelitian sebelumnya dapat dikemukakan hipotesis sebagai berikut:

$\mathrm{H}_{4}$ : Kompensasi finansial berpengaruh positif signifikan terhadap organizational citizenship behavior (OCB)

Penelitian yang dilakukan Yuniar dkk. (2011) menyatakan bahwa terdapat hubungan positif dan signifikan antara kepuasan kerja dengan organizational citizenship behavior (OCB). Penelitian Foote dan Tang (2008) juga menyatakan bahwa ada hubungan yang menunjukan signifikas antara kepuasan kerja dengan organizational citizenship behavior (OCB). Penelitian diperkuat oleh Sharma dan Bajpai (2011) dengan menyatakan bahwa keterlibatan dalam prilaku organisasi kewarganegaraan meningkatkan tingkat kepuasan kerja. Penelitian oleh Rini dkk. (2013) pada karyawan PT. Plasa Simpanglima Semarang menyatakan bahwa kepuasan kerja berpengaruh positif dan signifikan organizational citizenship behavior (OCB). Selanjutnya Najafi et al. (2011) juga menyatakan kepuasan kerja secara signifikan berdampak positif terhadap OCB. Penelitian oleh Chiboiwa et al. (2011) memperoleh hal yang sama yaitu mendapatkan temuan bahwa kepuasan kerja secara signifikan berdampak positif terhadap OCB. Berdasarkan landasan 
teori dan berbagai penelitian sebelumnya dapat dikemukakan hipotesis sebagai berikut :

$\mathrm{H}_{5}$ : Kepuasan kerja berpengaruh positif dan signifikan terhadap organizational citizenship behavior (OCB).

\section{METODE PENELITIAN}

Lokasi penelitian dilakukan pada perusahaan kontraktor PT. Dwi Eka Bakti yang berlokasi di Jalan Kenyeri No. 70 XX Denpasar, Bali. Lokasi ini dipilih karena ditemukan masalah yang terkait dengan keadilan organisasi, kompensasi finansial, kepuasan kerja dan organizational citizenship behavior (OCB). Selain itu, pemilihan lokasi ini didasarkan atas tersedianya data yang memadai dan mampu diolah peneliti. Penelitian ini dilakukan kepada seluruh karyawan yang ada di PT. Dwi Eka Bakti tapi tidak termasuk pimpinan atau direktur perusahaan.

Obyek penelitian ini adalah pengaruh keadilan organisasional (X1) terhadap kepuasan kerja (Y1), pengaruh kompensasi finansial (X2) terhadap kepuasan kerja (Y1), pengaruh keadilan organisasional (X1) terhadap organizational citizenship behavior (OCB) (Y2), kompensasi finansial (X2) terhadap organizational citizenship behavior (OCB) (Y2), serta pengaruh kepuasan kerja (Y1) terhadap organizational citizenship behavior (OCB) (Y2) di PT. Dwi Eka Bakti.

Populasi dalam penelitian ini adalah seluruh karyawan namun tidak melibatkan pimpinan atau direktur pada perusahaan PT. Dwi Eka Bakti yang berjumlah 40 orang, dengan jumlah karyawan masing-masing divisi sebagai berikut: 
Tabel 1.

Jumlah Karyawan Pada PT. Dwi Eka Bakti

\begin{tabular}{clc}
\hline No & \multicolumn{1}{c}{ Jabatan } & Jumlah Karyawan \\
\hline 1 & Supervisor Marketing & 1 \\
2 & Supervisor Operasional & 1 \\
3 & Supervisor Keuangan & 1 \\
4 & Supervisor Personalia dan Umum & 1 \\
5 & Staff Admin Marketing & 3 \\
6 & Staff Admin Proyek & 2 \\
7 & Staff Admin Keuangan & 3 \\
8 & Staff Admin Personalia & 1 \\
9 & Pelaksana Proyek & 5 \\
10 & Tenaga Tehnik & 22 \\
& Total & $\mathbf{4 0}$ \\
\hline Sumber: Data diolah, 2018
\end{tabular}

Sampel merupakan bagian dari jumlah dan karakteristik yang dimiliki oleh populasi. Dalam penelitian ini mengingat jumlah populasi hanya 40 orang, maka seluruh populasi dijadikan sampel. Metode penentuan sampel yang digunakan dalam penelitian ini adalah sampling jenuh. Sampling jenuh merupakan suatu teknik penentu sampel apabila semua anggota populasi digunakan sebagai sampel (Sugiyono, 2016:96).

Teknik analisis yang digunakan dalam penelitian ini adalah teknik analisis path (path analysis) yang dimana teknik analisis path dapat didefinisikan sebagai perluasan dari analisis linier berganda dalam memperkirakan hubungan kausalitas antara yang telah ditetapkan berdasarkan teori. Analisis jalur digunakan untuk menentukan hubungan 3 variabel atau lebih dalam mengkonfirmasi dan menolak hipotesis (Ghozali, 2011: 249). Teknik analisis jalur akan digunakan dalam menguji besarnya kontribusi yang dinyatakan oleh koefisien jalur pada setiap diagram jalur dari hubungan kausal atau sebab akibat yang tercipta dari variabel eksogen terhadap variabel endogen. Pada dasarnya perhitungan koefisien jalur 
membutuhkan perhitungan dari analisis korelasi dan regresi yang kemudian dituangkan dalam software berupa SPSS for windows. Terdapat dua anak panah dalam pembentukan diagram jalur, yaitu: anak panah satu arah yang mencerminkan satu pengaruh variabel eksogen terhadap variabel endogen dan anak panah dua arah yang mencerminkan suatu hubungan yang terjadi antara variabel eksogen.

\section{HASIL PENELITIAN}

Teknik analisis yang digunakan dalam penelitian ini adalah teknik analisis path (path analysis) yang dimana teknik analisis path dapat didefinisikan sebagai perluasan dari analisis linier berganda dalam memperkirakan hubungan kausalitas antara yang telah ditetapkan berdasarkan teori.Berdasarkan hasil analisis data dengan program SPSS dapat dilihat koefisien regresi pada persamaan regresi 1 dan 2 pada Tabel 2 dan Tabel 3 sebagai berikut:

Tabel 2.

Hasil Analisis Jalur Persamaan Regresi 1

\begin{tabular}{|c|c|c|c|c|c|c|}
\hline & \multirow[b]{2}{*}{ Model } & \multicolumn{2}{|c|}{$\begin{array}{c}\text { Unstandardized } \\
\text { Coefficients }\end{array}$} & \multirow{2}{*}{$\begin{array}{c}\text { Standardized } \\
\text { Coefficients } \\
\text { Beta }\end{array}$} & \multirow[b]{2}{*}{$\mathbf{t}$} & \multirow[b]{2}{*}{ Sig } \\
\hline & & B & Std. Error & & & \\
\hline \multirow[t]{6}{*}{1} & (Constant) & 0,760 & 1,244 & & 0,611 & 0,545 \\
\hline & $\begin{array}{c}\text { Keadilan } \\
\text { organisasional }\end{array}$ & 0,896 & 0,196 & 0,536 & 4,569 & 0,000 \\
\hline & $\begin{array}{l}\text { Kompensasi } \\
\text { Finansial }\end{array}$ & 0,518 & 0,142 & 0,427 & 3,636 & 0,001 \\
\hline & $\mathrm{R} 2$ & $: 0,858$ & & & & \\
\hline & F hitung & $: 111,713$ & & & & \\
\hline & Sig. F & $: 0,000$ & & & & \\
\hline
\end{tabular}

Berdasarkan Tabel 2 dapat diketahui bahwa pengaruh gabungan variabel keadilan organisasional dan kompensasi finansial terhadap kepuasan kerja adalah 
Ni Made Reni Budi Damayanti, Pengaruh......

$\mathrm{R}^{2}=0,858$ ini berarti keadilan organisasional dan kompensasi finansial mempengaruhi kepuasan kerja sebesar 85,8 persen dan sisanya 14,2 persen dipengaruhi oleh variabel lainnya. Hal ini menyatakan bahwa keadilan organisasional dan kompensasi finansial sangat diperlukan dalam menciptakan kepuasan kerja pada karyawan, semakin adil pimpinan memperlakukan bawahannya secara hormat dan bermartabat, tanpa memandang situasi dan jabatan seorang karyawan, serta selalu memperhatikan gaji dan insentif yang layak untuk setiap karyawan pada perusahaan, maka secara langsung akan menciptakan kepuasan kerja yang tinggi, yang nantinya akan berdampak pada semangat karyawan dalam bekerja sehingga akan bepengaruh pada kemajuan perusahaan.

Pada hasil analisis jalur substruktur 1 seperti yang disajikan pada table 4.8maka diperoleh nilai koefisien beta adalah Nilai $\beta 1$ sebesar 0,536 . Berdasarkan hasil analisis pengaruh keadilan organisasional terhadap kepuasan kerja diperoleh nilai Sig. $\mathrm{t}$ sebesar 0,000 dengan nilai koefisien beta 0,536 Nilai Sig. t 0,000 0,05 mengindikasikan bahwa $\mathrm{H}_{0}$ ditolak dan $\mathrm{H}_{1}$ diterima. Hasil ini mempunyai arti memiliki arti keadilan organisasional berpengaruh positif terhadap kepuasan kerja, dengan kata lain jika pada saat faktor keadilan organisasional meningkat maka kepuasan kerja akan meningkat sebesar 0,536. Hal ini tidak lepas dari peran penting perlakuan anatara pimpinan dengan bawahan, interaksi seluruh karyawan pada perusahaan, beban kerja yang dirasakan adil serta karyawan mendapatkan segala hak-hak mereka sesuai dengan apa yang mereka kontribusikan kepada perusahaan. 
Diperoleh nilai koefisien beta adalah nilai $\beta 2$ sebesar 0,427 , berdasarkan hasil analisis pengaruh kompensasi finansial terhadap kepuasan kerja diperoleh nilai Sig. t sebesar 0,001 dengan nilai koefisien beta 0,427 Nilai Sig. t 0,001 0,05 mengindikasikan bahwa $\mathrm{H}_{0}$ ditolak dan $\mathrm{H}_{1}$ diterima. Hasil ini mempunyai arti bahwa kompensasi finansial berpengaruh positif dan signifikan terhadap kepuasan kerja, dengan kata lain jika faktor kompensasi finansial meningkat maka kepuasan kerja akan meningkat sebesar 0,427. Hal ini tidak lepas dari adanya sistem pembayaran yang adil dan sesuai dengan harapan karyawan, pemberian gaji, insentif, tunjangan serta bonus yang rutin dan sesuai dengan aturan yang telah disepakati antara karyawan dengan perusahaan, maka secara langsung karyawan merasa puas dengan imbalan yang telah diterimanya, sehingga nantinya akan berpengaruh kepada kinerja seluruh karyawan.

Tabel 3.

Hasil Analisis Jalur Persamaan Regresi 2

\begin{tabular}{|c|c|c|c|c|c|c|}
\hline \multicolumn{2}{|c|}{ Model } & \multicolumn{2}{|c|}{$\begin{array}{l}\text { Unstandardized } \\
\text { Coefficients } \\
\text { Std. }\end{array}$} & $\begin{array}{c}\text { Standardized } \\
\text { Coefficients } \\
\text { Beta } \\
\end{array}$ & $\mathbf{t}$ & Sig \\
\hline 1 & (Constant) & $-2,077$ & 1,056 & & $-1,967$ & 0,057 \\
\hline & $\begin{array}{l}\text { Keadilan } \\
\text { organisasional }\end{array}$ & 0,447 & 0,207 & 0,238 & 2,160 & 0,037 \\
\hline & $\begin{array}{l}\text { Kompensasi } \\
\text { Finansial }\end{array}$ & 0,396 & 0,140 & 0,290 & 2,824 & 0,008 \\
\hline & Kepuasan Kerja & 0,530 & 0,139 & 0,471 & 3,815 & 0,001 \\
\hline & $\mathrm{R} 2$ & $: 0,922$ & & & & \\
\hline & F hitung & $: 141,950$ & & & & \\
\hline & Sig. F & $: 0,000$ & & & & \\
\hline
\end{tabular}

Berdasarkan Tabel 3 dapat diketahui bahwa pengaruh gabungan variabel keadilan organisasional dan kompensasi finansial terhadap kepuasan kerja adalah 
Ni Made Reni Budi Damayanti, Pengaruh......

$\mathrm{R}^{2}=0,922$ ini berarti keadilan organisasional dan kompensasi finansial mempengaruhi organizational citizenship behavior sebesar 92,2 persen dan sisanya 7,8 persen dipengaruhi oleh variabel lainnya.Hal ini menyatakan bahwa keadilan organisasional dan kompensasi finansial memiliki peran penting dalam meningkatkan perilaku OCB, dimana semakin baik perusahaan dalam memperlakukan karyawan baik dukungan kepada seluruh karyawan tanpa memandang jabatan dan pemberian penghargaan yang adil sesuai dengan kinerja seorang karyawan serta adanya pembagian kompensasi finansial yang sesuai dengan beban kerja karyawan akan secara langsung mendorong karyawan untuk berperilaku OCB.

Pada hasil analisis jalur substruktur 2 seperti yang disajikan pada tabel3 diperoleh nilai koefisien beta adalah Nilai $\beta 3$ sebesar 0,238. Berdasarkan hasil analisis pengaruh keadilan organisasional terhadap organizational citizenship behavior diperoleh nilai Sig. $\mathrm{t}$ sebesar 0,037 dengan nilai koefisien beta 0,238, Nilai Sig. t 0,037 0,05 mengindikasikan bahwa $\mathrm{H}_{0}$ ditolak dan $\mathrm{H}_{1}$ diterima. Hasil ini mempunyai arti bahwa keadilan organisasional berpengaruh positif dan signifikan terhadap organizational citizenship behavior, dengan kata lain jika faktor keadilan organisasional meningkat maka organizational citizenship behavior akan meningkat sebesar 0,238. Hal ini tidak lepas dengan adanya perananan masing-masing karyawan baik atasan dan bawahan serta lingkungan kerja yang mendukung sehingga terciptanya kondisi yang nyaman dalam bekerja dan mengurangi sikap negatif seperti iri hati dan perdebatan antar karyawan sehingga akan tercipta perilaku OCB. 
Diperoleh nilai koefisien beta adalah Nilai $\beta 4$ sebesar 0,290. Berdasarkan hasil analisis pengaruh kompensasi finansial terhadap organizational citizenship behavior diperoleh nilai Sig. $\mathrm{t}$ sebesar 0,008 dengan nilai koefisien beta 0,290 Nilai Sig. t 0,008 0,05 mengindikasikan bahwa $\mathrm{H}_{0}$ ditolak dan $\mathrm{H}_{1}$ diterima. Hasil ini mempunyai arti bahwa kompensasi finansial berpengaruh positif dan signifikan terhadap organizational citizenship behavior, dengan kata lain jika faktor kompensasi finansial meningkat maka organizational citizenship behavior akan meningkat sebesar 0,290. Hal ini tidak lepas dari adanya peranan pimpinan atau direktur dalam pemberian kompensasi finansial yang memadai dan sesuai dengan beban kerja tiap karyawan, sehingga secara langsung akan menciptakan perilaku OCB yang tinggi.

Diperoleh nilai koefisien beta adalah Nilai $\beta 5$ sebesar 0,471. Berdasarkan hasil analisis pengaruh kepuasan kerja terhadap organizational citizenship behavior diperoleh nilai Sig. $\mathrm{t}$ sebesar 0,001 dengan nilai koefisien beta 0,471 Nilai Sig. t 0,001 0,05 mengindikasikan bahwa $\mathrm{H}_{0}$ ditolak dan $\mathrm{H}_{1}$ diterima. Hasil ini mempunyai arti bahwa kepuasan kerja berpengaruh positif dan signifikan terhadap organizational citizenship behavior, dengan kata lain jika faktor kepuasan kerja meningkat maka organizational citizenship behavior akan meningkat sebesar 0,471 . Hal ini karena kepuasan kerja berpengaruh terhadap prilaku OCB dimana kepuasan karyawan merupakan segala hal yang dapat dirasakan sehingga karyawan tersebut merasa puas dengan apa yang mereka rasakan baik dari beban kerja dan kenyamanan di lingkungan kerjanya akan secara langsung mendorong seorang karyawan untuk berperilaku OCB. 
Dalam Menguji nilai koefisien determinasi $\left(\mathrm{R}^{2}\right)$ dan variabel error (e) Berdasarkan model substruktural 1 dan substruktural 2, maka dapat disusun model diagram jalur akhir. Sebelum menyusun diagram jalur akhir, terlebih dahulu dihitung nilai standar error sebagai berikut :

$$
\begin{aligned}
& \mathrm{e}=\sqrt{1-K 1^{2}} \cdot \ldots \ldots \ldots \ldots \ldots \ldots \ldots \ldots \ldots \\
& \mathrm{e}_{1}=\sqrt{1-K 1^{2}}=\sqrt{1-0,858}=0,376 \\
& \mathrm{e}_{2}=\sqrt{1-K 2^{2}}=\sqrt{1-0,922}=0,279
\end{aligned}
$$

Berdasarkan perhitungan pengaruh error (e) didapat hasil pengaruh error $\left(\mathrm{e}_{1}\right)$ sebesar 0,376 Dan pengaruh error $\left(\mathrm{e}_{2}\right)$ sebesar 0,279. Hasil Koefisien determinasi total adalah sebagai berikut:

$$
\begin{aligned}
\mathrm{R}_{\mathrm{m}}^{2} & =1-\left(\mathrm{Pe}_{1}\right)^{2}\left(\mathrm{Pe}_{1}\right)^{2} \ldots \ldots \ldots \ldots \ldots \ldots \ldots \ldots \\
& =1-(0,376)^{2}(0,279)^{2} \\
= & 1-(0,141)(0,077)=1-0,011=0,989
\end{aligned}
$$

Nilai determinasi total sebesar 0,989 Mempunyai arti bahwa sebesar 98,9 persen variasi organizational citizenship behavior dipengaruhi oleh keadilan organisasional, kompensasi finansial dan kepuasan kerja sedangkan sisanya 1,1 persen dijelaskan oleh faktor lain yang tidak dimasukan kedalam model.

Tabel 4.

Pengaruh Langsung dari Keadilan Organisasional $\left(\mathbf{X}_{1}\right)$, Kompensasi Finansial $\left(\mathbf{X}_{2}\right)$, Kepuasan Kerja $\left(\mathrm{Y}_{1}\right)$, dan $\mathrm{OCB}\left(\mathrm{Y}_{2}\right)$.

\begin{tabular}{clccc}
\hline No & \multicolumn{1}{c}{ Pengaruh Variabel } & Koefisien & Sig & Keterangan \\
\hline 1 & Keadilan Organisasi - Kepuasan kerja & 0,536 & 0,000 & Positif signifikan \\
2 & Kompensasi Finansial - Kepuasan kerja & 0,427 & 0,001 & Positif signifikan \\
3 & Keadilan Organisasi - OCB & 0,238 & 0,037 & Positif signifikan \\
4 & Kompensasi Finansial - OCB & 0,290 & 0,008 & Positif signifikan \\
5 & Kepuasan Kerja - OCB & 0,471 & 0,001 & Positif signifikan \\
\hline \multicolumn{2}{l}{ Sumber: Data diolah, 2018 }
\end{tabular}


Tabel 4 menunjukkan bahwa pengaruh langsung antara variabel keadilan organisasional dan kepuasan kerja memiliki nilai pengaruh langsung sebesar 0,536. Antara kompensasi finansial dan kepuasan kerja memiliki nilai pengaruh langsung sebesar 0,427. Variabel keadilan organisasional dan organizational citizenship behavior memiliki nilai pengaruh langsung sebesar 0,238. Variabel kompensasi finansial dan organizational citizenship behavior memiliki nilai pengaruh langsung sebesar 0,290. Dan variabel kepuasan kerja dan organizational citizenship behavior memiliki nilai pengaruh langsung sebesar 0,471.

Pengaruh tidak langsung variabel keadilan organisasional (X1) terhadap organizational citizenship behavior (Y2) melalui kepuasan kerja (Y1) didapat dari perhitungan sendiri dengan menghitung hasil perkalian Indirect effect $=\beta 1 \times \beta 5=$ $0,536 \times 0,471=0,252$. Hal ini berarti keadilan organisasional dapat mempengaruhi organizational citizenship behavior (OCB) melalui kepuasan kerja. Semakin baik keadilan organisasional yang diterima karyawan oleh perusahaan, maka semakin puas karyawan dalam bekerja sehingga berdampak terhadap meningkatnya prilaku OCB karyawan.

Pengaruh tidak langsung variabel kompensasi finansial (X2) terhadap organizational citizenship behavior (Y2) melalui kepuasan kerja (Y1) didapat dari perhitungan sendiri dengan menghitung hasil perkalian Indirect effect $=\beta 2 \times \beta 5=$ $0,427 \times 0,471=0,201$. Hal ini berarti bahwa kompensasi finansial dapat mempengaruhi organizational citizenship behavior (OCB) melalui kepuasan kerja. Semakin sesuai kompensasi yang diberikan perusahaan, maka puas karyawan 
Ni Made Reni Budi Damayanti, Pengaruh......

dalam bekerja sehingga berdampak terhadap meningkatnya prilaku OCB karyawan.

Pengaruh total variabel keadilan organisasional (X1) terhadap organizational citizenship behavior $(\mathrm{Y} 2)$ Total effect $=\beta 3+(\beta 1 \times \beta 5)=0,238+$ $(0,536 \times 0,471)=0,490$. Berdasarkan perhitungan tersebut dapat diketahui keadilan organisasional berpengaruh total secara positif terhadap organizational citizenship behavior (OCB) karyawan, hal ini berarti semakin baik penerapan keadilan organisasional yang diberikan oleh perusahaan maka secara langsung dan tidak langsung melalui kepuasan kerja akan berpengaruh terhadap peningkatan perilaku organizational citizenship behavior (OCB) karyawan.

Pengaruh total variabel kompensasi finansial (X2) terhadap organizational citizenship behavior $(\mathrm{Y} 2)$ Total effect $=\beta 3+(\beta 2 \times \beta 5)=0,238+(0,427 \times 0,471)$ $=0,439$. Berdasarkan perhitungan tersebut dapat diketahui kompensasi finansial berpengaruh total secara positif terhadap organizational citizenship behavior (OCB) karyawan, hal ini berarti semakin baik kompensasi finansial yang diberikan oleh perusahaan maka secara langsung dan tidak langsung melalui kepuasan kerja akan berpengaruh terhadap peningkatan perilaku organizational citizenship behavior (OCB) karyawan.

Berdasarkan permasalahan dalam Penelitian ini dapat rangkum secara ringkas pada Table 5 . 
Tabel 5.

Pengaruh Tidak langsung dan Pengaruh Total dari Keadilan Organisasional $\left(X_{1}\right)$, Kompensasi Finansial $\left(\mathbf{X}_{2}\right)$, Kepuasan Kerja $\left(Y_{1}\right)$, dan OCB $\left(Y_{2}\right)$

\begin{tabular}{cccc}
\hline No & Pengaruh Variabel & $\begin{array}{c}\text { Pengaruh Tidak } \\
\text { Langsung (Melalui } \\
\text { Kepuasan Kerja) }\end{array}$ & $\begin{array}{c}\text { Pengaruh } \\
\text { Total }\end{array}$ \\
\hline 1 & Keadilan Organisasi - Kepuasan kerja & - & 0,536 \\
2 & Kompensasi Finansial - Kepuasan kerja & - & 0,427 \\
3 & Keadilan Organisasi - OCB & 0,252 & 0,490 \\
4 & Kompensasi Finansial - OCB & 0,201 & 0,439 \\
5 & Kepuasan Kerja - OCB & - & 0,471 \\
\hline Sumber: Data diolah, 2018
\end{tabular}

Faktor yang berhubungan dengan perilaku organizational citizenship behavior (OCB) dalam penelitian ini adalah keadilan organisasional, kompensasi finansial dan kepuasan kerja. Implikasi teoritis berkaitan dengan OCB secara konsisten memperkuat teori sebelumnya bahwa keadilan organisasional, kompensasi finansial dan kepuasan kerja mempengaruhi seseorang untuk berperilaku OCB. Ketika pimpinan suatu perusahaan mampu berlaku adil dan adanya kesejahteraan secara finansial yang diterapkan secara konsisten kepada seluruh karyawannya maka akan secara langsung meningkatkan kepuasan kerja. Karyawan akan bekerja tanpa beban dan tidak adanya perasaan iri atau saling menjatuhkan satu sama lainnya sehingga akan terciptanya perilaku OCB yang tinggi. Hal ini dapat mendukung penelitian yang telah diungkapkan pada hipotesis penelitian, sehingga Penelitian ini telah memeperjelas hubungan antar variabel tersebut.

Penelitian ini diharapkan akan memberikan kontribusi positif bagi semua pihak khususnya karyawan dan perusahaan PT. Dwi Eka Bakti. Bagi karyawan hendaknya mampu menjalin hubungan yang baik antar rekan kerja serta 
memberikan kontribusi melebihi peran inti atau tugasnya terhadap perusahaan. Bagi pihak perusahaan harus mampu mengelola SDM nya dengan baik salah satunya mendorong karyawannya untuk mau berperilaku OCB, dengan memperhatikan keadilan serta kesejahteraan karyawan yang nantinya akan meningkatkan rasa kepuasan dalam bekerja. Adanya interaksi yang baik antar atasan dan bawahan menjadi hal yang penting dalam kenyamanan bekerja. Bila perilaku OCB yang dimiliki karyawan tinggi maka hal tersebut dapat menjadi faktor utama berhasil tidaknya perusahaan mempertahankan eksistensinya.

Berdasarkan penelitian yang telah dilakukan, terdapat beberapa hal yang menjadi keterbatasan di dalam Penelitian ini. Adapun keterbatasan yang dapat diuraikan adalah penelitian hanya dilakukan pada satu perusahaan kontraktor yang memiliki ruang lingkup dua divisi saja yaitu divisi pengadaan dan jasa pelaksana kontruksi dan bangunan sipil, sedangkan masih banyak perusahaan kontraktor yang bekerjasama dengan PLN dengan divisi yang bervariasi dengan jumlah karyawan yang lebih banyak sehingga hasil Penelitian ini tidak bisa di generalisasi di tempat lainnya.

Responden enggan untuk memberikan tanggapan yang sesuai dengan fakta, terutama terkait dengan pertanyaan-pertanyaan yang berhubungan dengan informasi tentang kepuasan yang telah diterima terhadap perusahaan.

\section{SIMPULAN DAN SARAN}

Berdasarkan hasil pembahasan, dapat di tarik beberapa simpulan bahwa keadilan organisasional berpengaruh positif dan signifikan terhadap kepuasan kerja. Dengan demikian semakin baik keadilan organisasional yang diterapkan, 
maka kepuasan kerja karyawan akan semakin meningkat. Kompensasi finansial berpengaruh positif dan signifikan terhadap kepuasan kerja. Dengan demikian semakin baik kompensasi finansial yang diberikan, maka kepuasan kerja karyawan meningkat. Keadilan organisasional berpengaruh positif dan signifikan terhadap organizational citizenship behavior. Dengan demikian semakin baik penerapan keadilan organisasional pada suatu perusahaan, maka perilaku organizational citizenship behavior semakin meningkat. Kompensasi finansial berpengaruh positif dan signifikan terhadap organizational citizenship behavior. Dengan demikian semakin baik dan konsisten kompensasi finansial yang diberikan, maka semakin meningkat perilaku organizational citizenship behavior. Kepuasan kerja berpengaruh positif dan signifikan terhadap organizational citizenship behavior. Dengan demikian semakin tinggi kepuasan kerja karyawan terhadap perusahaan, maka semakin meningkat pula perilaku organizational citizenship behavior.

Berdasarkan hasil analisis dan simpulan, maka saran yang dapat diberikan kepada pihak-pihak bahwa perusahaan PT. Dwi Eka Bakti diharapkan menerapkan sebuah peraturan baku yang telah disepakati bersama serta mampu diterapkan dan ditaati secara konsisten bersama, sehingga menjadi pedoman dalam melaksanakan aktivitas bekerja, sehingga mempermudah dalam pemberian sanksi pelanggaran bagi setiap karyawan yang melanggarnya. Perusahaan PT. Dwi Eka Bakti diharapkan mampu memberikan kesejahteraan baik finansial maupun non finansial kepada karyawannya sesuai dengan beban kerja masingmasing, sehingga adanya semangat dan kepuasan dalam bekerja. Perusahaan PT. 
Dwi Eka Bakti sebaiknya meningkatkan dalam hal kualitas pelayanan khususnya pada produk-produk yang ditawarkan pada PT. PLN baik dalam bidang pengadaan dan jasa sehingga mampu bersaing dengan perusahaan-perusahaan kontraktor lainnya. Dalam penelitian mendatang perlu ditimbangkan untuk menggunakan variabel lain, seperti dukungan organisasi, lingkungan kerja fisik dan lainnya, yang dapat mendukung dan memperkaya informasi yang diperoleh.

\section{REFERENSI}

Ahmad, Noor Azmi, Azri Abdul Aziz, Syaquif Yasin Kamaruddin, Azdel Abdul Aziz and Mohn Faeez Saiful Bakhtiar. (2012). The Influence of Direct Financial Compensation Towards Future-Graduates Career Choice In Hoel Industry. Journal of Tourism, Hospitality and Culinary Arts. 4 (3), pp:18-30.

Anas, Khaidiri.(2013). Pengaruh Kompensasi dan Lingkungan Kerja Terhadap Kepuasan Kerja Karyawan PT. Karya Mitra Muda. Jurnal Manajemen, 2(1): h: 1-11.

Bhatti Komal Khalid, and Samina Nawab. (2011). Influence of Employee Compensation on Organizational Commitment and Job Satisfaction: A Case Study of Educational Sector Pakistan. Internasional Journal of Business and Social Science, 2(8), pp: 25-32

Cropanzano, R., Bowen, D. E., \& Gilland, S. W. (2007).The management of organizational justice.Academy of Management Perspectives, 21 (4), pp 34-48.

Chiboiwa, Malvern W, Crispen Chipunza and Michall O. Samuel. (2011). Evaluation of Job Satisfaction and Organisastional Citizenship Behaviour: Case Study of Selected Organisastional in Zimbabwe. African Journal of Business Management, 5 (7), pp: 2910-2918.

Choi, W. S., Jun S. H., Lee J. K. (2015). A study on the impact of material, social, symbolic reward on ocb: moderate effect of the rank. Journal of Economics, Business and Management. 3 (3) : 377-382

Danan dan Hasanbasri, (2007). Hubungan Kepuasan Kerja Dan Komitmen Organisasi Dengan Organizational Citizenship Behavior (OCB) Di Politeknik Kesehatan Banjarmasin.WPS No.2 Januari 2007 1st draft, Program Magister Kebijakan dan Manajemen Pelayanan Kesehatan, Universitas Gadjah Mada Yogyakarta.c1 h : 0605-2007 
Devi, Ni Putu Ayu Archita Kumala dan Desak Ketut Sintaasih. (2016). Organizational Citizenship Behavior, Kepemimpinan Transaksional, Dan Komitmen Organisasional: Pengaruhnya Terhadap Kinerja Karyawan. Jurnal Ekonomi dan Bisnis Universitas Udayana. 5 (11) pp: 7418-7445

Erbasi, Ali and Tugay Arat, (2012), The Effect if Financial and Non-Financial Incetives on Job Satisfaction: An Examination of Food Chain Premises in Turkey. International Business Research, 5(10):pp:138-145.

Fatimah, Amiraa and Halim. (2011). The relationship between organizational justice, organizational citizenship behavior and job satisfaction. Pertanika Journal of Social Science \& Humanity, 19 (S): pp: 115-121.

Fatt, Choong Kwai., Khin, Edward W S., and Heng, Tioh N. (2010). The Impact of Organizational Justice on Employee's Job Satisfaction : The Malaysian Computer Companies Perspectives. Amarican Jurnal of Economics and Business Administrasion. 2(1), pp: 56-63.

Faruk, Omer. (2013). Relationship Between The Facets of Job Satisfaction and The Dimensional of Organizational Citizenship Behavior. The Journal of Faculty of Economics and Administrative Sciences, 18 (1), pp: 243-269

Foote, David A and Thomas Li-Ping Tang. (2008). Job Satisfaction and Organizational Citizenship Behavior (OCB): does Team Commitment make a difference in Self-directed Teams. Management Decision, 46(6): pp:933-947

Ghozali, Imam. (2011). Aplikasi Analisis Multivariate dengan Program IBM SPSS 19. Semarang: Badan Penerbit Universitas Diponogoro.

Handoko, T. Hani. (2001). Manajemen Personalia \& Sumberdaya Manusia Cetakan ke-15, Yogyakarta : BPFE-Yogyakarta.

Huang, Chun-Chen., You, Ching Sing, and Tsai, Ming Tien. (2012). A Multidimensional Analysis of Ethical Climate, Job Satisfaction, Organizational Commitment, and Organizational Citizenship Behaviors, Nursing Ethics, 19(4), pp. 513-529.

Ibrahim, Mohamed E.dan Ann O. Perez. (2014). Effects of organizational justice, employee satisfaction, and gender on employees' commitment: evidence from the uae.International Journal of Business and Management, 9 (2). pp. $45-59$.

Islam, Talat, Zulifqar Ahmad, Ishfaq Ahmed, Ashfaq Ahmad, Muhammad Saeed, and Muhammad Saeed. (2012). Does Compensation and Demographical Variable Influence on Teachers Commitment and Job Satisfaction? A 
Study of University of the Punjab, Pakistan. International Journal of Business and Management, 7(4), pp: 35- 43.

Kusumaningtyas Intan, dan Alwi Suddin. (2012). Pengaruh Kompensasi Terhadap Kepuasan Kerja Karyawan Bank Mega dengan Motivasi Kerja sebagai Variabel Moderasi. Jurnal manajemen Sumber Daya Manusia, 6(2), h:95-105

Leo, Andy. (2014). Pengaruh Kompensasi Finansial dan Kepemimpinan Terhadap Kepuasan kerja Lokasi PT. Mandiri Jayaindo Utama Pekanbaru. Jurnal Online Mahasiswa, 1(1): pp: 1- 16.

Marissa. (2010). Pengaruh Persepsi Keadilan Organisasi Terhadap Komitmen Organisasi Karyawan PT. Garuda Indonesia (Persero). Skripsi. Universitas Islam Negri Syarif Hidayatullah. Jakarta

Mustafa Eq, Zainal. (2008). Pengaruh Keadilan Distributif dan Prosedural Justice Terhadap Kesejahteraan dan Kepuasan Kerja Serta Mogok Kerja Karyawan Industi Tekstil Di Eks-Keresidenan Surakarta. Majalah Ekonomi FE. Universitas Islam Indonesia, 8(2), pp:164-183.

Najafi, Sajjad, Ali Noruzy, Hemin Khezri Azar, Sajad Nazari-Shirkouhi and Mohammad Reza Dalvand. (2011). Investigating the relationship between organizational justice, psychological empowerment, job satisfaction, organizational commitment and organizational citizenship behavior: An empirical model. African Journal of Business Management, 5 (13), pp:5241-5248.

Nwibere, B.M. (2014). Organisational justice as a determinant of organizational citizenship behavior in the Nigerian work environment: a study of selected universities in the niger delta region. International Journal of Business and Management, Vol. 9.No. 4. pp. 191-205.

Perdana, Adam M.P. (2010). Pengaruh Persepsi Gaya Kepemimpinan dan Kepuasan Kerja terhadap OCB pada Karyawan PT. Bumi Serpong Damai Tbk. Tangerang. Skripsi Sarjana Jurusan Psikologi pada Fakultas Psikologi Universitas Islam Negeri, Syarif Hidayatullah. Jakarta. Series/Report no : 0111-05-7849;1012 PSI p

Ratnaningsih. S.Y. (2013).Pengaruh kepuasan kerja dan komitmen organisasi terhadap organizational citizenship behavior (OCB). Media Mahardika. 11 (2), h: 113-138.

Rini, Dyah P., Rusdarti dan Suparjo. (2013). Pengaruh Komitmen Organisasi Terhadap Organizational Citizenship Behaviour (OCB) (Studi pada pT. 
Plasa Simpanglima Semarang). Jurnal Ilmiah Dinamika Ekonomi dan Bisnis, 1 (1), h: 2337-6082 69).

Riyadi, Slamet. (2011). Pengaruh Kompensasi Finansial, Gaya Kepemimpinan, dan Motivasi Kerja Terhadap Kinerja Karyawan Pada Perusahaan Manufaktur di Jawa Timur. Jurnal Manajemen dan Kewirausahaan, 13 (1): pp:40-45.

Retnaningsih, Sudarwati. (2007). Analisis Pengaruh Keadilan Kompensasi, Peran Kepemimpinan, dan Kepuasan Kerja Terhadap Komitmen Organisasi Dalam Meningkatkan Kinerja Karyawan (Studi Kasus: Pada Sentral Pengolahan Pos Semarang). Thesis Jurusan Manajemen Fakultas Ekonomi dan Bisnis Universitas Diponegoro, Semarang.

Robbins, Stephen P. dan Judge, T.A. (2008). Perilaku Organisasi "Organizational Behavior". Buku 1. Jakarta : Salemba Empat. Simamora, Henry. 2004. Manajemen Sumber Daya Manusia. Edisi 1 Yogyakarta.

Robbins, Stephen P. dan Timothy A. Judge. (Ratna Saraswati dan Febriella Sirait, Penerjemah). (2015). Perilaku Organisasi “Organizational Behaviour”, 16th Edition. Jakarta: Salemba Empat.

Roohi, Mohammad dan Mohammad Feizi. (2013). Organizational Justice and Organizational Citizenship Behaviour In Islamic Azad University. International Journal of Management Research and Review, 3(3), pp: 2513-2521.

Samudra, Putra Angga, Kusdi Rahardjo, dan M. Djudi Mukzam. (2014). Pengaruh Kompensasi Finansial Terhadap Kinerja (studi pada karyawan PT. Bank Jatim Cabang Malang). Jurnal Administrasi Bisnis, 7(2):pp:1-9.

Sareshkeh, S.K., Ghaziani, F.G., and Tayebi, S.M. (2012). Impact of Organizational Justice Perceptions on Job Satisfaction and Organizational Commitment: The Iranian Sport Federation Perspective. Annals of Biological Research. 3(8), pp: 4229-4238

Sharma, Jai Prakash., Naval Bajpai and Umesh Holani. (2011). Organizational Citizenship Behaviour in Public and Private Sector and It's impac on Job Satisfaction: A Comparative Study in Indian Perspective. International Journal of Business and Management, 6(1), pp: 67-75.

Septiadi, I Made dan W. G. Supartha. (2013). Pengaruh Kepemimpinan, Komunikasi, dan Lingkungan Kerja Fisik Terhadap Kepuasan kerja Pada PT. BPR Sriartha Lestari Denpasar. E-Journal Universitas Udayana. 2 (8) : pp: 986 - 1001. 
Sugiyono. (2016). Metode Penelitian Administrasi, Bandung : Alfabeta

Suwardi, Joko Utomo. (2011). Pengaruh Motivasi Kerja, Kepuasan Kerja, dan Komitmen Organisasional Terhadap Kinerja Pegawai, Analisis Manajemen. 1(5) pp: 75-86

Syah, Harits. (2013). Pengaruh Kompensasi Finansial Terhadap Kepuasan Kerja Karyawan dan Motivasi Kerja Karyawan pada PT. Graha Raja Empat. Jurnal Ilmu Manajemen, 1(2): pp:462-471.

Salwa Hayati Hasan, Nasir Aziz, Muhammad Adam (2011). Pengaruh lingkungan kerja terhadap kinerja aktivis pada Lembaga Swadaya Masyarakat di Kota Banda Aceh, Jurnal Ilmu Manajemen, 1(1): pp:1-22.

Swaminathan, Samanvitha dan P. David Jawahar. (2013). Job Satisfaction as a Predictor of Organizational Citizenship Behaviour: An Empirical Study. Global Journal of Business Research, 7 (1), pp: 71-80.

Tampi, Gina Sheelsia. (2013). Kepemimpinan dan Kompensasi pengaruhnya terhadap Kinerja Karyawan dan dampaknya terhadap Organizational Citizenship Baehavior (OCB). Jurnal EMBA, 1(3): pp: 921-929.

Utama, Mudiartha, Ni wayan Mujiati, dan Komang Ardana. (2001). Manajemen Sumber Daya Manusia, Buku Ajar Fakultas Ekonomi Universitas Udayana, Denpasar.

Waspodo, Agus AWS dan Lussy Minadaniati. (2012). Pengaruh Kepuasan Kerja dan Iklim Organisasi terhadap Organizational Citizenship Behavior (OCB) Karyawan pada PT. Trubus Swadaya. Jurnal Riset Manajemen Sains Indonesia (JRMSI), 3(1): pp:1-16.

Widyaningrum, Mahmudah Enny. (2010). Pengaruh Keadilan Organisasi Terhadap Kepuasan Kerja, Komitmen dan Organizational Citizenship Behaviour Pegawai (Studi Kasus Di Rumah Sakit Bersalin Pura Raharja Surabaya) Tahun 2009. Majalah Ekonomi, pp : 100-118

Wibowo. (2012). Manajemen Kinerja. Edisi Ketiga. Jakarta: PT. Raya Gratindo Persada.

William, Theophilus dan Roy Setiawan. (2013). Pengaruh Komitmen Organisasional dan Kepuasan Kerja Karyawan Terhadap Organizational Citizenship Behaviour (OCB) Di PT. CB Capital. AGORA, 1 (1), pp :1-8

Yasadiputra, Komang Aris. (2014). Pengaruh Organizational Justice serta Job Insecurity Terhadap Job Satisfaction Pegawai Kontrak Pada PT. Wico Interna, Singaraja-Bali. Jurnal Manajemen Strategi Bisnis dan Kewirausahaan, 8 (1) pp : 52-67 
E-Jurnal Manajemen, Vol. 8, No. 2, 2019: 7955 - 7985

Yuniar, I Gusti Ayu Agung Yesika, Harlina Nurtjahjanti, dan Diana Rusnawati. (2011). Hubungan Antara Kepuasan Kerja dan Resiliensi dengan Organizational Citizenship Behaviour (OCB) pada Karyawan Kantor Pusat PT. BPD Bali. Jurnal Psikologi Undip, 9 (1). Pp: 2878-6260 